\author{
Hanna SOMMER ${ }^{1}$ \\ Hubert SOMMER ${ }^{2}$ \\ Grzegorz ZAKRZEWSKI ${ }^{3}$
}

Po ataku nożownika $w$ galerii handlowej

w Stalowej Woli jedna osoba nie żyje, a dwie osoby sq w szpitalu w stanie krytycznym.

Kilka zostało lżej rannych.

20.10.2017r.

\title{
OCENA WYBRANYCH SKEADOWYCH WPLYWAJACYCH NA KOMFORT PRZEBYWANIA KLIENTÓW W WIELKOPOWIERZCHNIOWYCH OBIEKTACH HANDLOWYCH
}

\begin{abstract}
Artykuł jest próbą znalezienia wspólnego mianownika dla trzech oddzielnych dziedzin nauki: ekologii, ergonomii, bezpieczeństwa i higieny pracy, które przenikają się wzajemnie i tworza nowe nieznane rozwiązania, można by rzec in statu nascendi ${ }^{4}$ w pewien sposób obrazujący stan i poziom badań w przestrzeni wielkopowierzchniowego obiektu handlowego. W obecnej dobie dominują dwa kierunki dociekań naukowych. Pierwszy za cel postawił sobie wyodrębnianie nowych gałęzi nauki z podstawowego źródła. Doskonałym przykładem tego kierunku jest medycyna, która wyodrębniła z podstawowego pnia nauki specjalności takie jak: kardiologia, neurologia, urologia i inne. Można by kolejne nauki przedstawiać spoglądając na człowieka jako źródło ich (nauk) zainteresowań. Motorem postępu jak zawsze są wiedza i postęp technologiczny. Te dwa nierozłączne elementy oddziałując na siebie inspirują się wzajemnie prowadząc do coraz nowszych odkryć. Nauka prawdopodobnie wymusi już w niedalekiej przyszłości na neurologii jej podział na specjalistę prawej i lewej półkuli mózgowej. Dla
\end{abstract}

${ }^{1}$ Dr Hanna Sommer, Katedra Nauk Humanistycznych, Wydział Zarządzania, Politechnika Rzeszowska, Al. Powstańców Warszawy 8, 35-959 Rzeszów, autor korespondencyjny; e-mail: hansom @ prz.edu.pl

Hanna Sommer, PhD, Department of Humanities, Faculty of Management, Rzeszów University of Technology, Al. Powstańców Warszawy 8, 35-959 Rzeszów, corresponding autor; e-mail: hansom@prz.edu.pl

${ }^{2}$ Dr Hubert Sommer, Katedra Historii i Teorii Wychowania, Wydział Pedagogiczny, Uniwersytet Rzeszowski, ul. ks. J. Jałowego 24, 35-010 Rzeszów; e-mail: hubsom@wp.pl

Hubert Sommer, PhD, Faculty of Pedagogy, Rzeszów University, ul. ks. J. Jałowego 24, 35-010 Rzeszów; e-mail: hubsom@wp.pl

${ }^{3}$ Dr inż. Grzegorz Zakrzewski, Akademia Pomorska w Słupsku Wydział Nauk o Zarządzaniu i Bezpieczeństwie Instytut Bezpieczeństwa Narodowego, ul. Arciszewskiego 22a, 76-200 Słupsk; e-mail: grzegorz.zakrzewski@apsl.edu.pl

Grzegorz Zakrzewski, PhD, Eng., Pomeranian University, Faculty of management Science and Security, ul. Arciszewskiego 22a, 76-200 Słupsk; email:grzegorz.zakrzewski@apsl.edu.pl

${ }^{4}$ https://sjp.pl/in+statu+nascendi (dostęp: 3 listopada 2017 r.). 
specjalistów taki proces wydaje się oczywisty. Drugi kierunek, to współdziałanie nauk w interdyscyplinarnej niszy, w której jak w soczewce skupiają się samodzielne dziedziny nauki, by jak najlepiej opisać badane zagadnienie. Na przykład zagadnienia bezpieczeństwa w komunikacji obejmują między innymi: projektowanie infrastruktury drogowej, technologię produkcji i eksploatacji pojazdów, zagadnienia prawne, ubezpieczeniowe zdrowotne oraz inne. Nie wymieniono tutaj wszystkich podmiotów, ale zagadnienie w sposób opisowy na zasadzie porównania, na potrzeby niniejszego artykułu zostało zdefiniowane.

Wracając do pierwotnych zamiarów podjęto próbę opisania wybranych zagadnień z ekologii, ergonomii, bezpieczeństwa i higieny pracy, próbując spojrzeć na to interdyscyplinarne zagadnienie przez pryzmat dociekań ekonomii. Autorzy sami nie określą, jaki kierunek jest im bliższy przyjmując zasadę, że to co dla jednych badaczy jest oczywiste, dla drugich stanowi pole do polemiki. Przedstawione zostaną wyniki sondażu diagnostycznego z wykorzystaniem ankiety.

Słowa kluczowe: wielkopowierzchniowe obiekty handlowe, ekologia, ergonomia, bezpieczeństwo i higiena pracy, ekonomia.

\section{WPROWADZENIE}

Przedmiotem badań będzie wielkopowierzchniowy obiekt handlowy ${ }^{5,6}$. Termin ten zagościł na dobre w słowniku nie tylko budowlańców, (również socjologów, ekologów). Po zmianach społeczno-ustrojowych, jakie wystąpiły w kraju po roku 90. ubiegłego wieku, stały się miejscem-siedliskiem spotkań ludzi. Na budowlę inżynierską autorzy spojrzą przez pryzmat osiągnięć naukowych ekologii ${ }^{7}$. W roku 1935 Arthur Tansley ${ }^{8}$ wprowadził pojęcie ekosystemu, jako podstawową ekologiczną jednostkę funkcjonalno-przestrzenną. Ekosystem stanowi obszar o względnie jednorodnych warunkach abiotycznych (biotop), zajęty przez odpowiadający tym warunkom zbiór gatunków powiązanych zależnościami troficznymi i paratroficznymi, przez który płynie strumień energii i materii. Zgodnie z tą definicją ekosystem tworzą dwa pozostające ze sobą w ścisłym związku komponenty:

- nieożywiony (biotop, zw. też siedliskiem), na który składają się gleba, woda i powietrze z ich właściwościami fizykochemicznymi oraz klimat, który istnieje niezależnie od biocenozy;

- ożywiony (biocenoza), złożony z kombinacji gatunków właściwych danemu biotopowi w danych warunkach geograficznych ${ }^{9}$. Z klasycznej definicji siedliska można w sposób prosty wyprowadzić definicję siedliska utechnicznionego, to jest takiego, które jest wytworem myśli ludzkiej i osiągnięć inżynierii, które zasiedla człowiek. Skrajne przypadki ekosystemu zagospodarowanego technicznie, to stacja orbitalna czy okręt podwodny z napędem atomowym.

5 Ustawa z dnia 11 maja 2007 r. o tworzeniu i działaniu wielkopowierzchniowych obiektów handlowych (Dz.U. z 2007 r. nr 127, poz. 880).

${ }^{6}$ Ustawa z dnia 25 września 2015 r. o zmianie ustawy o planowaniu i zagospodarowaniu przestrzennym (Dz.U. z 2015 r. poz. 1713).

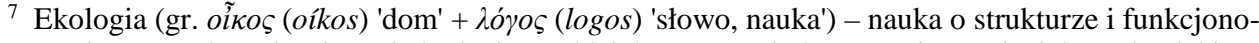
waniu przyrody, zajmująca się badaniem oddziaływań pomiędzy organizmami a ich środowiskiem oraz wzajemnie między tymi organizmami (czyli strukturą ekosystemów). https://pl.wikipedia.org/wiki/Ekologia (dostęp 3 listopada 2017 r.).

8 Sir Arthur George Tansley (ur. 15 sierpnia 1871, zm. 25 listopada 1955) - angielski botanik i ekolog, twórca terminu ekosystem (1935). https://pl.wikipedia.org/wiki/Arthur_Tansley

9 S. Borsuk (red.), Ochrona i ksztattowanie środowiska, Toruń-Bydgoszcz 1994, s. 9. 
Współczesna ergonomia ${ }^{10}$ zajmuje się nie tylko projektowaniem konstrukcji, stanowisk pracy (kokpitu pilota), urządzeń i narzędzi pracy oraz wyrobów powszechnego użytku. Jej rozwiązania i opracowania naukowe mają zastosowanie przy planowaniu warunków bytowych i rekreacyjnych (siedliska). Badany wielkopowierzchniowy obiekt handlowy jako miejsce handlu, rekreacji i wypoczynku musi zapewniać ergonomiczny komfort, relaks fizyczny i psychiczny, bezpieczeństwo higienę pracy, wypoczynek oraz ochronę środowiska naturalnego i utechnicznionego. Zagadnienia sztucznie wytworzonego siedliska należy zawsze rozpatrywać w aspekcie ekonomicznym. Wytworzenie tego pierwszego zawsze pociąga zmiany w środowisku naturalnym. Stworzenie sztucznego klimatu (dobranie temperatury, wilgotności, nie odczuwanie wymiany powietrza - uczucie przeciągu), czy komfortu świetlnego wymaga od inżynierów nie tylko projektowania stosownego ilorazu powierzchni okien do powierzchni oświetlanych w jasnej porze doby, a w jej ciemnej rozmieszczenie punktów świetlnych o określonych parametrach widma i mocy. To z kolei wiąże się wydatkowaniem energii, która jest pozyskiwana nie zawsze $\mathrm{z}$ odnawialnych źródeł.

\section{OGÓLNA CHARAKTERYSTYKA OBIEKTU}

W tabeli 1 zestawiono dziewięć największych galerii handlowych, których powierzchnia handlowa wynosi 70 000-110 $000 \mathrm{~m}^{2}$. Pierwszą dziesiątkę zamyka Galeria Rzeszów z powierzchnią $42000 \mathrm{~m}^{2}$. Powierzchnia ta jest standardem dla pozostałych galerii $\mathrm{w}$ miastach powyżej 100000 mieszkańców. Nie jest rolą autorów dokładnie analizować rozwiązania techniczne (np. parkingi o pojemności ponad 1000 samochodów) w samym centrum

Tabela 1. Zestawienie największych galerii handlowych w Polsce

\begin{tabular}{|c|l|l|c|}
\hline Lp. & \multicolumn{1}{|c|}{ Miasto } & \multicolumn{1}{|c|}{ Nazwa } & $\mathbf{m}^{\mathbf{2}}$ \\
\hline 1 & Warszawa 3 & Arkadia & 110000 \\
\hline 2 & Łódź 2 & Manufaktura & 110000 \\
\hline 3 & Łódź & Port-Łódź & 103000 \\
\hline 4 & Kraków & Bonarka & 91000 \\
\hline 5 & Katowice & Silesia City Center & 84000 \\
\hline 6 & Warszawa & Park Handlowy Targówek & 80000 \\
\hline 7 & Wrocław & Magnolia Park & 80000 \\
\hline 8 & Warszawa & Wola Park & 73000 \\
\hline 9 & Kielce & Galeria Echo & 70000 \\
\hline 10 & Rzeszów & Galeria Rzeszów & 42000 \\
\hline
\end{tabular}

Źródło: opracowanie własne na podstawie: http://biznes.gazetaprawna.pl/galerie/779498,duze-zdjecie,8,najwieksze-centra-handlowe-w-polsce.html, http://www.urbanity.pl/podkarpackie/rzeszow/galeria-rzeszow,b3308 (dostęp: 4 listopada 2017 r.).

10 Termin ,ergonomia” został po raz pierwszy sformułowany przez wybitnego polskiego przyrodnika, profesora Instytutu Rolniczo-Leśnego w Marymoncie pod Warszawą W.B. Jastrzębowskiego. W roku 1857 Jastrzębowski ogłosił artykuł zatytułowany „Rys ergonomii, czyli Nauki o pracy opartej na prawach zaczerpniętych z Nauki Przyrody”. Pisał w nim m.in. „Nazwiskiem Ergonomii, wziętym od wyrazu greckiego ergon (praca) i nomos (prawo, zasada), oznaczamy Naukę o Pracy. http://ergonomia-polska.com/07_03_ergonomia.htm (dostęp: 4 listopada 2017 r.). 
handlowym i obszarze około towarzyszącym, którego powierzchnia w przypadku Manufaktury wynosi 27 ha, ale jeden parametr zasługuje na uwagę, to jest liczba „odwiedzających”, która dla Arkadii przekracza liczbę $21 \mathrm{mln}$ klientów rocznie ${ }^{11}$. Osobnym zagadnieniem jest spiętrzenie przebywania populacji ludzi w określonym czasie, którym są okresy przedświąteczne często połączone $\mathrm{z}$ długim weekendem. Taka populacja $\mathrm{w}$ tak małym

Tabela 2. Dane rynkowe za III kwartał 2017 roku w kwestii obiektów handlowych

\begin{tabular}{|c|c|c|c|c|c|c|c|c|}
\hline Parametr & Polska & $\begin{array}{l}\text { Aglome- } \\
\text { racja war- } \\
\text { szawska }\end{array}$ & $\begin{array}{l}\text { Konurba- } \\
\text { cja kato- } \\
\text { wicka }\end{array}$ & $\begin{array}{l}\text { Aglome- } \\
\text { racja trój- } \\
\text { miejska }\end{array}$ & Lublin & $\begin{array}{l}\text { Aglome- } \\
\text { racja } \\
\text { szczeciń- } \\
\text { ska }\end{array}$ & $\begin{array}{l}\text { Aglome- } \\
\text { racja wro- } \\
\text { cławska }\end{array}$ & Toruń \\
\hline Podaż $\mathrm{m}^{2}$ & 11375900 & 1551900 & 1122660 & 747000 & 360100 & 287600 & $56300 C$ & 137900 \\
\hline Pustostany $\%$ & 4.2 & 2.6 & 5.9 & 3.1 & 3.7 & 3.3 & 4.1 & 2.6 \\
\hline $\begin{array}{l}\text { Powierzchnie } \\
\text { w budowie } \mathrm{m}^{2}\end{array}$ & 644300 & 169300 & 92000 & 62000 & 26000 & 17000 & 64000 & 0 \\
\hline $\begin{array}{l}\text { Nasycenie } \\
\mathrm{m}^{2} / 1000 \\
\text { mieszkańców }\end{array}$ & 295 & 598 & 525 & 717 & 1058 & 516 & 826 & 681 \\
\hline
\end{tabular}

Źródło: opracowanie własne na podstawie: https://www.retailmap.pl/pl/statystyki/miasta (dostęp: 4 listopada 2017 r.).

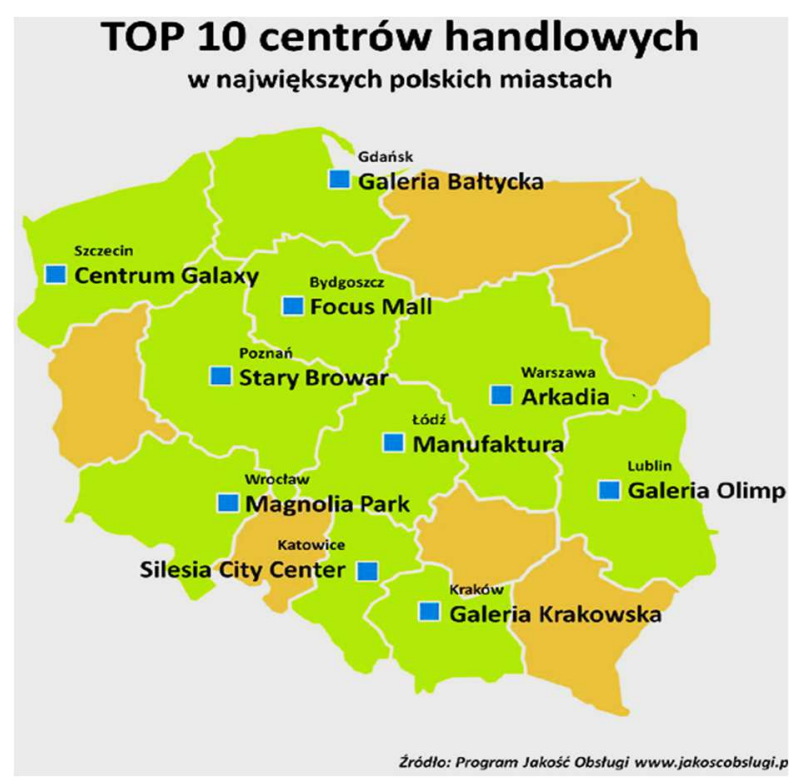

Rysunek 1. Rozmieszczenie największych galerii w Polsce

Źródło: https://urodaizdrowie.pl/ranking-najlepszych-galerii-handlowych-w-polsce (dostęp: 4 listopada 2017 r.).

${ }^{11} \mathrm{https}: / /$ urodaizdrowie.pl/ranking-najlepszych-galerii-handlowych-w-polsce (dostęp: 4 listopada 2017 r.). 
siedlisku to wyzwanie dla wszystkich służb zarządzających powierzchnią wielkopowierzchniowego obiektu handlowego. Przestrzeń handlowo-usługowa z sektorami wypoczynku może być powodem wygenerowania zdarzeń destrukcyjnych zależnych od administratora jak i zdarzeń losowych i celowych mających za cel zmianę parametrów siedliska.

W tabeli 2 przedstawiono dane rynkowe za III kwartał 2017 roku. Zaobserwowano w skali kraju ,nasycenie” rynku przestrzenią wielkopowierzchniowych obiektów handlowych. Osobną kwestią jest rozmieszczenie geograficzne wielkopowierzchniowych obiektów handlowych. Na mapie-rysunku 1 widać, że największe galerie są rozmieszczone w pasie centralnym Polski w układzie południkowym. Pokrywa się to z geograficzną zamożnością Polaków. Rejony północno-wschodniej, północnej i środkowo-zachodniej części kraju nie mają w swym krajobrazie takich mega centrów handlowych. W rejonach tych obsługę klientów przejęły mniejsze centra handlowe o powierzchni nie przekraczającej $40000 \mathrm{~m}^{2}$.

\section{METODOLOGICZNY ASPEKT BADAŃ WŁASNYCH}

Autorzy niniejszego opracowania badaniami objęli (stosunkowo niewielką - 75 respondentów) ale w miarę reprezentatywną grupę dorosłych Polaków o różnej płci i wieku, legitymujących się zróżnicowanym stopniem zurbanizowania środowiska czy też posiadanym wykształceniem. Obrazuje to tabela nr 3.

Tabela 3. Populacja badanych

\begin{tabular}{|c|c|c|c|}
\hline \multirow{2}{*}{\multicolumn{2}{|c|}{ Kategorie }} & \multicolumn{2}{|c|}{$\begin{array}{c}\text { Ogółem } \\
\text { dla } N=75=100 \%\end{array}$} \\
\hline & & $\mathbf{N}$ & $\%$ \\
\hline \multirow{2}{*}{ Płeć } & Kobiety dla N $=31=100 \%$ & 31 & 41,3 \\
\hline & Mężczyźni dla $\mathrm{N}=44=100 \%$ & 44 & 58,7 \\
\hline \multirow{3}{*}{ Wiek } & $18-30$ lat dla $\mathrm{N}=21=100 \%$ & 21 & 28 \\
\hline & $31-50$ lat dla $\mathrm{N}=32=100 \%$ & 32 & 42,7 \\
\hline & Powyżej 51 lat dla $\mathrm{N}=22=100 \%$ & 22 & 29,3 \\
\hline \multirow{2}{*}{$\begin{array}{l}\text { Miejsce } \\
\text { zamieszkania }\end{array}$} & Wieś dla $\mathrm{N}=24=100 \%$ & 24 & 32 \\
\hline & Miasto dla $\mathrm{N}=51=100 \%$ & 51 & 68 \\
\hline \multirow{4}{*}{ Wykształcenie } & Podstawowe dla $\mathrm{N}=7=100 \%$ & 7 & 9,3 \\
\hline & Zawodowe dla $\mathrm{N}=11=100 \%$ & 11 & 14,7 \\
\hline & Średnie dla $N=33=100 \%$ & 33 & 44 \\
\hline & Wyższe dla $\mathrm{N}=24=100 \%$ & 24 & 32 \\
\hline
\end{tabular}

Źródło: opracowanie własne.

W badanej próbie kobiety stanowiły nieco ponad $41 \%$ populacji, mężczyźni blisko $60 \%$. W przypadku wieku autorzy badań odnotowali, iż największą grupę respondentów stanowili ci badani, którzy znajdowali się w przedziale wiekowym 31-50 (blisko 43\% ankietowanych), zbliżone są wartości procentowe osób z dwóch pozostałych kategorii (odpowiednio: $28 \%$ dla badanych w wieku $18-30$ i 29,3\% - dla respondentów powyżej 51 roku życia). 
Znacząco wyższy jest odsetek ankietowanych, którzy na stałe zamieszkują w mieście (blisko $70 \%$ w badanej grupie), aniżeli osób, które na co dzień zamieszkują w mieście (32\%). Jeśli natomiast wziąć pod uwagę wykształcenie respondentów, to najmocniej reprezentowani byli Ci, którzy legitymują się średnim wykształceniem (44\%), najmniej autorzy odnotowali tych, którzy swoją edukację zakończyli na szkole podstawowej (9,3\%).

Zważywszy, że ujęto powyżej najpopularniejsze dane metryczkowe wykorzystywane w badaniach empirycznych, można stwierdzić, że badana populacja mogła stanowić (w pewnym stopniu oczywiście) standardowy przekrój polskiego społeczeństwa, co miało znaczący wpływ na dalszy przebieg badań i ich ostateczne rezultaty.

Zasadniczą kwestią, która stała się punktem odniesienia dla autorów niniejszego opracowania było uzyskanie odpowiedzi na następujące pytanie, a mianowicie na co ankietowani zwracają uwagę w wielkich centrach handlowych podczas tradycyjnych zakupów. Skorelowano to z płcią badanych respondentów, a wyniki obrazuje tabela nr 4.

Tabela 4. Co jest ważne w dużych centrach handlowych w korelacji z płcią badanych?

\begin{tabular}{|c|c|c|c|c|c|c|}
\hline \multirow{3}{*}{$\begin{array}{l}\text { Co jest dla Pani/Pana istotne w dużych } \\
\text { centrach handlowych? }\end{array}$} & \multicolumn{6}{|c|}{ Płeć badanych } \\
\hline & \multicolumn{2}{|c|}{$\begin{array}{c}\text { kobiety } \\
\text { dla } \mathrm{N}=31\end{array}$} & \multicolumn{2}{|c|}{$\begin{array}{l}\text { mężczyźni } \\
\text { dla } N=44\end{array}$} & \multicolumn{2}{|c|}{$\begin{array}{c}\text { ogółem } \\
\text { dla } N=75\end{array}$} \\
\hline & $\mathbf{N}$ & $\%$ & $\mathbf{N}$ & $\%$ & $\mathbf{N}$ & $\%$ \\
\hline $\begin{array}{l}\text { Bezpieczeństwo związane z publicznym cha- } \\
\text { rakterem obiektu }\end{array}$ & 9 & 29,1 & 42 & 95,4 & 51 & 68 \\
\hline $\begin{array}{l}\text { Ergonomia stanowisk wystawienniczych/ } \\
\text { sprzedażowych, punktów degustacji pro- } \\
\text { duktu, testów/pomiaru odzieży/sprzętu }\end{array}$ & 25 & 80,1 & 23 & 52,3 & 48 & 64 \\
\hline Ekologiczne wyroby i produkty & 23 & 74,2 & 35 & 79,6 & 58 & 77,3 \\
\hline Komfort świetlny & 2 & 6,4 & 3 & 6,8 & 5 & 6,7 \\
\hline Komfort akustyczny & 5 & 16,1 & 7 & 15,9 & 12 & 16 \\
\hline Komfort cieplny & 4 & 12,9 & 4 & 9,1 & 8 & 10,7 \\
\hline Reklama & 22 & 70,1 & 13 & 29,6 & 35 & 46,7 \\
\hline Zasady BHP & 16 & 51,6 & 40 & 90,1 & 56 & 74,7 \\
\hline Zasady zachowania & 14 & 45,2 & 39 & 88,6 & 53 & 70,1 \\
\hline
\end{tabular}

Uwaga: suma procentowa nie jest równa 100, ponieważ respondenci mogli wybrać więcej niż jedną odpowiedź.

Źródło: opracowanie własne.

Uzyskane rezultaty badań wskazują jednoznacznie na kilka istotnych prawidłowości. I tak, opinie kobiet i mężczyzn bardzo mocno się różnicują w wielu, istotnych kwestiach. Dla badanych respondentów bowiem najważniejszą sprawą jest to, by centrum handlowe spełniało wszystkie wymogi bezpieczeństwa niezbędne przy jego publicznym funkcjonowaniu (taki pogląd prezentowało ponad $95 \%$ ankietowanych), gdy tymczasem wśród kobiet taką opinię podzielało niecałe $30 \%$. Z kolei ergonomia stanowisk (...) była istotna dla ponad $80 \%$ respondentek i 52,3\% respondentów. Niezwykle istotne zasady BHP zdecydowanie mocniej w swoich wypowiedziach akcentowali mężczyźni $(90,1 \%)$ aniżeli kobiety (niecałe 52\% ankietowanych). Nie ma również zgodności wśród badanych względem reklamy 
(o wiele częściej jest ona ważna dla kobiet - 70,1\%, aniżeli dla mężczyzn - zaledwie 29,6\%). Zbliżone wyniki autorzy uzyskali w kwestii ekologii wyrobów (odpowiednio: $74,2 \%$ i $79,6 \%)$, komfortu akustycznego $(16,1 \%$ i $15,9 \%)$ oraz komfortu cieplnego $(12,9 \%$ i $9,1 \%$ ). Zdywersyfikowane są za to wyniki dotyczące zasad zachowania (kobiety akcentują je tylko w 45,2\%, zaś mężczyźni w blisko 90\%).

Wnioski wydają się w tym wypadku aż nazbyt oczywiste. Okazało się bowiem (w wyniku przeprowadzonych badań), iż płeć ankietowanych ma znaczący wpływ na prezentowane przez nich postawy względem tego, na co powinno się zwrócić uwagę w wielkich centrach handlowych. Dla ankietowanych respondentów najważniejsze powinno być bezpieczeństwo związane z publicznym charakterem obiektu, zasady BHP a także zasady zachowania, kobiety natomiast większą rolę przywiązują do ergonomii stanowisk wystawowych, ekologii wyrobów czy nawet reklamy.

Z powyższego można pokusić się o następującą konkluzję, a mianowicie bezpieczeństwo dużych obiektów handlowych wydaje się być zdecydowanie bardziej istotne dla dorosłych mężczyzn niż dorosłych kobiet.

A jaki wpływ na analizowaną kwestię będzie mieć miejsce zamieszkania badanych? Wyniki zobrazowano w tabeli nr 5.

Tabela 5. Co jest ważne w dużych centrach handlowych w korelacji z miejscem zamieszkania?

\begin{tabular}{|c|c|c|c|c|c|c|}
\hline \multirow{3}{*}{$\begin{array}{c}\text { Co jest dla Pani/Pana istotne w dużych } \\
\text { centrach handlowych? }\end{array}$} & \multicolumn{6}{|c|}{ Miejsce zamieszkania } \\
\hline & \multicolumn{2}{|c|}{$\begin{array}{c}\text { wieś } \\
\text { dla } \mathrm{N}=\mathbf{2 4}\end{array}$} & \multicolumn{2}{|c|}{$\begin{array}{c}\text { miasto } \\
\text { dla } N=51\end{array}$} & \multicolumn{2}{|c|}{$\begin{array}{c}\text { ogółem } \\
\text { dla } N=75\end{array}$} \\
\hline & $\mathbf{N}$ & $\%$ & $\mathbf{N}$ & $\%$ & $\mathbf{N}$ & $\%$ \\
\hline $\begin{array}{l}\text { Bezpieczeństwo związane z publicznym cha- } \\
\text { rakterem obiektu }\end{array}$ & 16 & 66,7 & 35 & 68,7 & 51 & 68 \\
\hline $\begin{array}{l}\text { Ergonomia stanowisk wystawienniczych/ } \\
\text { sprzedażowych, punktów degustacji pro- } \\
\text { duktu, testów/pomiaru odzieży/sprzętu }\end{array}$ & 15 & 62,5 & 33 & 64,7 & 48 & 64 \\
\hline Ekologiczne wyroby i produkty & 11 & 45,8 & 47 & 92,1 & 58 & 77,3 \\
\hline Komfort świetlny & 1 & 4,2 & 4 & 7,8 & 5 & 6,7 \\
\hline Komfort akustyczny & 2 & 8,3 & 10 & 19,6 & 12 & 16 \\
\hline Komfort cieplny & 1 & 4,2 & 7 & 13,7 & 8 & 10,7 \\
\hline Reklama & 5 & 20,9 & 30 & 58,8 & 35 & 46,7 \\
\hline Zasady BHP & 14 & 58,3 & 42 & 82,3 & 56 & 74,7 \\
\hline Zasady zachowania & 13 & 54,2 & 40 & 78,4 & 53 & 70,1 \\
\hline
\end{tabular}

Uwaga: suma procentowa nie jest równa 100, ponieważ respondenci mogli wybrać więcej niż jedną odpowiedź.

Źródło: opracowanie własne.

Uzyskane wyniki znacząco różnią się od tych, w których autorzy korelowali płeć badanych $\mathrm{z}$ ich odpowiedziami w analizowanej kwestii. I tak, o ile ankietowane respondentki nierzadko miały zupełnie inne zdanie w kluczowych sprawach aniżeli badani mężczyźni, o tyle w przypadku stopnia zurbanizowania środowiska badanych, różnice w wypowie- 
dziach mieszkańców wsi nie odbiegają już tak wyraźnie, od tych, które prezentują mieszkańcy miast. Zarówno jedna, jak i druga grupa ankietowanych mocno w swoich wypowiedziach akcentuje bezpieczeństwo związane z publicznym charakterem obiektu (odpowiednio: $66,7 \%$ i 68,7\%). Na ekologiczność produktów zdecydowanie mocniejszy nacisk kładą mieszkańcy miast (odpowiednio: 92,1\% i 45,8\%). Podobnie rzecz wygląda z przestrzeganiem zasad BHP - 82,3\%, to mieszkańcy legitymujący się miejscem zamieszkania w dużych aglomeracjach, nieco ponad 58\% - to mieszkańcy wsi. Najrzadziej wybieraną kategorią zwłaszcza, przez mieszkańców wsi jest komfort świetlny i cieplny (zaledwie w 4,2\%).

Reasumując możemy stwierdzić, iż miejsce zamieszkania różnicuje opinie badanych na analizowaną kwestię bezpieczeństwa. I tak dla mieszkańców aglomeracji miejskich bardzo istotna jest ekologiczność serwowanych produktów i przestrzeganie zasad BHP, gdy tymczasem dla mieszkańców legitymujących się pochodzeniem wiejskim obok wymienionych wyżej kategorii istotna jest ekonomia stanowisk wystawienniczych. Obie grupy badanych mniej więcej w takim samym stopniu dostrzegają istotną rolę bezpieczeństwa związanego z publicznym przeznaczeniem obiektu.

Kolejna zmienna, na którą zwrócili uwagę autorzy opracowania to wiek badanych respondentów. Jak obrazuje to tabela 6 , w tym przypadku różnice w wypowiedziach badanych nie odbiegały zasadniczo od tych, które zamieszczono w poprzednich tabelach.

Tabela 6. Co jest ważne w dużych centrach handlowych w korelacji z wiekiem badanych?

\begin{tabular}{|c|c|c|c|c|c|c|c|c|}
\hline \multirow{3}{*}{$\begin{array}{c}\text { Co jest dla Pani/Pana istotne } \\
\text { w dużych centrach handlowych? }\end{array}$} & \multicolumn{8}{|c|}{ Wiek badanych } \\
\hline & \multicolumn{2}{|c|}{$\begin{array}{c}\text { 18-30 lat dla } \\
\mathrm{N}=21\end{array}$} & \multicolumn{2}{|c|}{$\begin{array}{c}31-50 \text { lat dla } \\
\quad \mathrm{N}=32\end{array}$} & \multicolumn{2}{|c|}{\begin{tabular}{|c|} 
powyżej 51 lat \\
dla N = 22 \\
\end{tabular}} & \multicolumn{2}{|c|}{$\begin{array}{l}\text { ogółem } \\
\text { dla } N=75\end{array}$} \\
\hline & $\mathbf{N}$ & $\%$ & $\mathbf{N}$ & $\%$ & $\mathbf{N}$ & $\%$ & $\mathbf{N}$ & $\%$ \\
\hline $\begin{array}{l}\text { Bezpieczeństwo związane z publicz- } \\
\text { nym charakterem obiektu }\end{array}$ & 13 & 61,9 & 25 & 78,1 & 1 & 66,6 & 51 & 68 \\
\hline $\begin{array}{l}\text { Ergonomia stanowisk wystawienni- } \\
\text { czych/sprzedażowych, punktów de- } \\
\text { gustacji produktu, testów/pomiaru } \\
\text { odzieży/sprzętu }\end{array}$ & 12 & 57,1 & 23 & 71,8 & 13 & 59,1 & 48 & 64 \\
\hline Ekologiczne wyroby i produkty & 15 & 71,4 & 26 & 81,2 & 17 & 77,2 & 58 & 77,3 \\
\hline Komfort świetlny & 1 & 4,8 & 3 & 9,4 & 1 & 4,6 & 5 & 6,7 \\
\hline Komfort akustyczny & 3 & 14,3 & 6 & 18,7 & 3 & 13,6 & 12 & 16 \\
\hline Komfort cieplny & 1 & 4,8 & 5 & 15,6 & 2 & 9,1 & 8 & 10,7 \\
\hline Reklama & 7 & 33,3 & 19 & 59,4 & 9 & 40,1 & 35 & 46,7 \\
\hline Zasady BHP & 16 & 76,2 & 23 & 71,8 & 17 & 77,3 & 56 & 74,7 \\
\hline Zasady zachowania & 11 & 52,4 & 21 & 65,6 & 21 & 95,4 & 53 & 70,1 \\
\hline
\end{tabular}

Uwaga: suma procentowa nie jest równa 100, ponieważ respondenci mogli wybrać więcej niż jedną odpowiedź.

Źródło: opracowanie własne.

Wiek respondentów jest tą zmienną, która wskazuje na istotne zależności. I tak, dla respondentów powyżej 51. roku życia najważniejszą rolę wpływającą na szeroko rozumiane bezpieczeństwo w wielkich centrach handlowych odgrywają właściwe zasady zachowania 
(ponad $95 \%$ badanych zaakcentowało takie stanowisko). Najrzadziej wybierali tę kategorię odpowiedzi najmłodsi z ankietowanych (przedział wiekowy 18-30 - nieco ponad 52,4\%). Dla nich z kolei zdecydowanie ważniejsze są zasady BHP oraz ekologiczność wyrobów i produktów (odpowiednio: 76,2\% i 71,4\%). Z kolei respondenci legitymujący się przedziałem wiekowym 31-50 ogromną rolę przypisywali wspomnianej wyżej ekologiczności produktów (ponad 81\%), ale również i bezpieczeństwu związanemu z publicznym charakterem obiektu (78,1\% badanych). Bardzo nisko został oceniony (przez wszystkie grupy wiekowe) komfort świetlny (odpowiednio: 4,8\%; 9,4\% i 4,6\%) i tzw. komfort cieplny $(4,8 \% ; 15,6 \%$ i $9,1 \%$ ).

Po głębszej analizie uzyskanych danych, które autorzy skorelowali tym razem z wiekiem badanych można stwierdzić, że w każdej grupie wiekowej są jakieś priorytety, na które zwracają oni uwagę w kwestii bezpieczeństwa w wielkich centrach towarowych i najczęściej mają one związek nie tylko z zasadami BHP czy dobrego zachowania, ale również ekologicznością produktów, a także z bezpieczeństwem związanym z publicznym charakterem obiektu.

Ostatnią zmienną wykorzystaną przez autorów w badaniach było wykształcenie.

Tabela 7. Co jest ważne w dużych centrach handlowych w korelacji z wykształceniem badanych?

\begin{tabular}{|c|c|c|c|c|c|c|c|c|}
\hline \multirow{3}{*}{$\begin{array}{c}\text { Co jest dla Pani/Pana istotne } \\
\text { w dużych centrach handlowych? }\end{array}$} & \multicolumn{8}{|c|}{ Wykształcenie badanych } \\
\hline & \multicolumn{2}{|c|}{\begin{tabular}{|c|} 
zawodowe dla \\
$\mathrm{N}=11=100 \%$ \\
\end{tabular}} & \multicolumn{2}{|c|}{\begin{tabular}{|c|} 
średnie dla \\
$\mathbf{N}=33=100 \%$ \\
\end{tabular}} & \multicolumn{2}{|c|}{\begin{tabular}{|c|} 
wyższe dla \\
$\mathrm{N}=\mathbf{2 4}=\mathbf{1 0 0 \%}$ \\
\end{tabular}} & \multicolumn{2}{|c|}{$\begin{array}{c}\text { Ogółem } \\
\text { dla } N=75\end{array}$} \\
\hline & $\mathbf{N}$ & $\%$ & $\mathbf{N}$ & $\%$ & $\mathbf{N}$ & $\%$ & $\mathbf{N}$ & $\%$ \\
\hline $\begin{array}{l}\text { Bezpieczeństwo związane z publicz- } \\
\text { nym charakterem obiektu }\end{array}$ & 2 & 18,2 & 26 & 78,8 & 23 & 95,8 & 51 & 68 \\
\hline $\begin{array}{l}\text { Ergonomia stanowisk wystawienni- } \\
\text { czych/sprzedażowych, punktów de- } \\
\text { gustacji produktu, testów/pomiaru } \\
\text { odzieży/sprzętu }\end{array}$ & 7 & 63,6 & 23 & 69,7 & 18 & 75 & 48 & 64 \\
\hline Ekologiczne wyroby i produkty & 5 & 45,4 & 30 & 90,1 & 23 & 95,8 & 58 & 77,3 \\
\hline Komfort świetlny & - & - & - & - & 5 & 20,8 & 5 & 6,7 \\
\hline Komfort akustyczny & - & - & 7 & 21,2 & 5 & 20,8 & 12 & 16 \\
\hline Komfort cieplny & 1 & 9,1 & 4 & 27,3 & 3 & 12,5 & 8 & 10,7 \\
\hline Reklama & 5 & 45,4 & 17 & 51,6 & 13 & 54,2 & 35 & 46,7 \\
\hline Zasady BHP & 1 & 9,1 & 32 & 96,9 & 23 & 95,8 & 56 & 74,7 \\
\hline Zasady zachowania & 1 & 9,1 & 30 & 90,1 & 22 & 91,7 & 53 & 70,1 \\
\hline
\end{tabular}

Uwaga: suma procentowa nie jest równa 100, ponieważ respondenci mogli wybrać więcej niż jedną odpowiedź.

Źródło: opracowanie własne.

Wykształcenie badanych na tyle różnicuje uzyskane rezultaty, iż warto pochylić się nad nimi przy ich empirycznej analizie. I tak, im jest ono wyższe, tym mocniej akcentuje się bezpieczeństwo związane z publicznym charakterem obiektu (odpowiednio: $95,8 \%$, to respondenci legitymujący się wykształceniem wyższym, 78,8\% - średnim i zaledwie 18,2\% - zawodowym). Znacznie wyżej pozycjonują zasady BHP i zasady zachowania respondenci 
ze średnim wykształceniem (odpowiednio: 96,9\% i 90,1\%). Równie wysoko ocenia je inteligencja $(95,8 \%$ i 91,7\%). Dla ankietowanych legitymujących się wykształceniem zawodowym owe zasady odgrywają znikomą rolę, podobnie komfort cieplny (po 9,1\% badanych). Dla tej grupy respondentów zdecydowanie ważniejsza jest ergonomia stanowisk (blisko 64\%) bądź też ekologiczność wyrobów czy nawet reklama (po 45,4\%). Zarówno komfort świetlny, jak i komfort akustyczny nie mają dla tej grupy badawczej żadnego znaczenia. Ani jednej odpowiedzi autorzy badań w tej kwestii nie odnotowali.

Wnioski wydają się w tym wypadku aż nazbyt oczywiste. Okazuje się bowiem, że wykształcenie badanych ma istotny wpływ na prezentowane przez nich poglądy dotyczące bezpieczeństwa robienia zakupów w wielkich centrach towarowych. Im jest ono wyższe, tym mocniej akcentowane są takie kategorie odpowiedzi jak zasady BHP, ekologiczność produktów czy ogólne zasady zachowania w sytuacjach kryzysowych.

Ostatnią kwestią poruszoną przez autorów tego krótkiego opracowania była próba odpowiedzi przez ogół badanych respondentów na pytanie: jaki jest ich zdaniem poziom bezpieczeństwa w dużych centrach handlowych? Wyniki zobrazowano w tabeli $\mathrm{nr} 8$. W tym wypadku punktem odniesienia stali się wszyscy respondenci niezależnie od płci, miejsca zamieszkania czy posiadanego wykształcenia.

Tabela 8. Poziom bezpieczeństwa w dużych centrach handlowych w opinii badanych

\begin{tabular}{|l|c|c|}
\hline \multicolumn{1}{|c|}{$\begin{array}{c}\text { Jaki jest Pani/Pana zdaniem poziom bezpieczeństwa } \\
\text { w dużych centrach handlowych? }\end{array}$} & \multicolumn{2}{|c|}{$\begin{array}{c}\text { Ogół badanych dla } \\
\text { N=75=100\% }\end{array}$} \\
\cline { 2 - 3 } & $\mathbf{N}$ & $\mathbf{\%}$ \\
\hline $\begin{array}{l}\text { 1. Zdecydowanie wysoki (nie dostrzegam absolutnie żadnych zagrożeń pod- } \\
\text { czas robienia zakupów w takich centrach) }\end{array}$ & 17 & 22,7 \\
\hline $\begin{array}{l}\text { 2. Raczej wysoki (po doniesieniach medialnych i wydarzeniach, jakie mają } \\
\text { miejsce na świecie pewien niepokój może się pojawić u każdego) }\end{array}$ & 28 & 37,3 \\
\hline $\begin{array}{l}\text { 3. Trudno powiedzieć (nie potrafię w tej kwestii zająć jednoznacznego sta- } \\
\text { nowiska) }\end{array}$ & 19 & 25,3 \\
\hline $\begin{array}{l}\text { 4. Raczej niski (coraz częściej będąc w takich centrach odczuwam pewien } \\
\text { dyskomfort, na co może mieć wpływ brak odpowiednio wyszkolonej grupy } \\
\text { osób dbających o bezpieczeństwo kupujących) }\end{array}$ & 7 & 9,3 \\
\hline $\begin{array}{l}\text { 5. Zdecydowanie niski (obecnie robienie zakupów w wielkich centrach han- } \\
\text { dlowych wiąże się z ogromnym ryzykiem, osoby zabezpieczające takie } \\
\text { obiekty są do tego kompletnie nieprzygotowane) }\end{array}$ & 4 & 5,4 \\
\hline
\end{tabular}

Źródło: opracowanie własne.

Wyniki wydają się być bardzo interesujące. Okazało się bowiem, iż badany ogół respondentów ma w analizowanej kwestii mocno spolaryzowane poglądy. Największy odsetek w ankietowanej populacji stanowili ci, dla których robienie zakupów w wielkich centrach handlowych jest raczej bezpieczne (ponad 37\% ogółu), choć z pewną nutką niepokoju, co ma oczywiście związek z doniesieniami medialnymi (chodzi tu zwłaszcza o ataki terrorystyczne w takich obiektach w Europie i na świecie). Blisko 23\% respondentów nie dostrzega żadnych zagrożeń podczas robienia zakupów w takich obiektach. Nieco ponad 5\% badanych uważa, że wielkie obiekty handlowe są bardzo źle zabezpieczone, a przybywanie w nich wiąże się z ogromnym ryzykiem. Ponad 9\% wśród ankietowanych stanowili ci, 
którzy obawiają się, iż słabo przeszkoleni ochraniarze w takich obiektach nie są w stanie odpowiednio zareagować w sytuacji kryzysowej. Najbardziej niepokojąca jest jednak dla autorów niniejszego opracowania inna kwestia, a mianowicie w badanej grupie co czwarta osoba nie potrafiła zająć w tak ważnym temacie żadnego stanowiska.

\section{ZAKOŃCZENIE}

Omawiając nowe formy handlu wielkopowierzchniowego jakim dla klientów są centra handlowe powstające w Polsce od połowy lat 90., należy zwrócić uwagę na różne aspekty istotne dla klientów tam przebywających. Centra handlowe zmieniły swoją powierzchnię, lokalizację, strukturę, architekturę, zakres funkcjonowania handlu wynikający z potrzeb rynku oraz przeobrażeń konsumpcji jak też stylu życia polskich konsumentów.

Następstwem rozwoju ośrodków handlu wielkopowierzchniowego są zmiany społeczno-kulturowe, które obserwujemy. Ośrodki handlowe trwale wpisały się w krajobraz polskich miast. Stały się miejscem spotkań czy też formą spędzania wolnego czasu. Centra handlowe w jednym miejscu skupiają wszystko, czego potrzebuje klient. Przyjemność kupowania w miejscu stworzonym do spełniania zachcianek potęguje emocje. Z tego względu właściciele obiektów handlowych wymagają od projektantów wnętrz kreatywności aby można było tworzyć więź z klientem.

Ważnym elementem jest komfort przebywania we wnętrzu takich budynków. Wielkie sieci handlowe intensywnie pracują nad jak najdłuższym zatrzymaniem klienta w sklepie. Pojawiają się coraz bardziej wyszukane metody „umilania” zakupów. Odpowiedni wystrój wnętrz oraz obsługa i specjalnie zaprojektowane ułożenie towarów stanowią już standard.

Wnioski, które płyną z przeprowadzonych badań wskazują że, współcześni Polacy niezależnie od płci, wieku, wykształcenia czy stopnia zurbanizowania środowiska dostrzegają zagrożenia, jakie mogą mieć miejsce w obiektach, które w Polsce cieszą się obecnie ogromną popularnością, niemniej jednak nie w takim stopniu, jak mogłoby to wyglądać w przypadku analogicznych badań w Republice Federalnej Niemiec czy we Francji. Dla większości obywateli naszego państwa ewentualne ataki terrorystyczne czy inne zagrożenia kryzysowe stanowią problem raczej surrealistyczny. Świadczyć o tym może następujący fakt, a mianowicie, w badanej populacji $60 \%$ respondentów czuje się na zakupach w wielkich centrach handlowych na tyle bezpiecznie, że raczej mało jest prawdopodobne, by zrezygnowali z nich w przyszłości.

\section{LITERATURA}

1. Borsuk S. (red.), Ochrona i kształtowanie środowiska, Toruń-Bydgoszcz 1994.

\section{AKTY PRAWNE}

1. Ustawa z dnia 11 maja 2007 r. o tworzeniu i działaniu wielkopowierzchniowych obiektów handlowych (Dz.U. z 2007 r., nr 127, poz. 880).

2. Ustawa z dnia 25 września 2015 r. o zmianie ustawy o planowaniu i zagospodarowaniu przestrzennym (Dz.U. z 2015 r., poz. 1713).

\section{NETOGRAFIA}

1. http://biznes.gazetaprawna.pl/galerie/779498,duze-zdjecie,8,najwieksze-centra-handlowew-polsce.html,poz.10 http://www.urbanity.pl/podkarpackie/rzeszow/galeria-rzeszow,b3308 
2. http://ergonomia-polska.com/07_03_ergonomia.htm

3. https://pl.wikipedia.org/wiki/Ekologia

4. https://pl.wikipedia.org/wiki/Arthur_Tansley

5. https://sjp.pl/in+statu+nascendi

6. https://urodaizdrowie.pl/ranking-najlepszych-galerii-handlowych-w-polsce

7. https://www.retailmap.pl/pl/statystyki/miasta

\section{RATING OF CHOSEN HABITATION FACTORS AFFECTING PEOPLE'S COMFORT LEVEL WHILE VISITING LARGE SHOPPING CENTRES}

This article attempts to find a common factor for three separate areas of research: ecology, ergonomics, labour safety and hygiene, that blend with each other and create new unknown solutions, which - one could say in statu nascendi - somehow depict the state and level of research in the area of large shopping centres. In the current state two directions dominate research. The aim of first of it is to isolate new research areas from its basic origin. A perfect example of it is medicine, that separated from the basic step of research specialities like: cardiology, neurology, urology and others. One could name other areas of research looking at human beings as the origin of its (research) field of interest. The motor of progress is - like always - knowledge and technological development. These two inseparable elements inspire each other through affecting each other, which results in new discoveries. Research will most likely force a soon division in neurology into specialists for the left and right cerebral hemispheres. Specialists find this of process obvious. The second direction is cooperation of research areas in a interdisciplinary niche, which convects independent research areas like a lens to best possible describe the examined issue. Communication security issues, i.e., include amongst others: planing of road infrastructure, vehicle production and exploitation technology, legal, insurance and health issues and others. Not all of the subjects have been named here, but the issue has been defined for the use of this article using description through comparison.

Back to the original goals, an attempt of describing chosen issues of ecology, ergonomics and labour safety and hygiene has been taken, trying to look at this interdisciplinary issue through the prism of economic investigation. The authors will not define on their own, which direction is more suitable for them, obeying the rule that what is obvious to some of the researchers may cause room for polemics for others. Results of a diagnostic opinion poll and questionnaire will be shown.

Keywords: large shopping centres, ecology, ergonomics, labour safety and hygiene, economics.

DOI: $10.7862 /$ rz.2018.hss.10

Przestano do redakcji: grudzień 2017 r.

Przyjęto do druku: kwiecień 2018 r. 